Volume 10 Issue 1 (2021) Pages 85-96

Ta'dib: Jurnal Pendidikan Islam

ISSN: 2528-5092 (Online) 1411-8173 (Print)

https://ejournal.unisba.ac.id/index.php/tadib/article/view/7847

\title{
ISLAMIC EDUCATION TEACHERS 'EFFORTS IN IMPROVING READING ABILITY TO WRITE THE QUR'AN THROUGH THE IQRO' METHOD IN CHILDREN WITH SPECIAL NEEDS
}

\author{
Nida Khofyya Hidayat ${ }^{1}$, M. Dahlan $\mathbf{R}^{2}$, Kholil Nawawi ${ }^{3}$ \\ Program Studi Pendidikan Agama Islam, Universitas Ibn Khaldun Bogor, Indonesia, ${ }^{1,2} 3$ \\ Email:khofyyanida2806@gmail.com¹,dahlan@uika-bogor.ac.id ${ }^{2}$, kholil@fai.uika-bogor.ac.id ${ }^{3}$ \\ DOI: https://doi.org/10.29313/tjpi.v10i1.7847 \\ Received: April 21 th, 2020. Accepted: June 1th, 2021. Published: June 1th, 2021.
}

\begin{abstract}
This study aims to determine how Islamic education teachers are trying to improve the ability to read and write the Qur'an through the Iqro 'method, and to find out the problems of the ability to read and write the Qur'an in children with special needs in SLB Bina Sejabtera. In this study, using a qualitative method which has natural characteristics as a source of direct data. The subject of this research is shown to the Islamic Religious Education Teacher. Researchers in this case applied several data collection techniques, namely observation, interviews and documentation. The results showed that the PAI teacher's efforts in improving the ability to read and write the Qur'an through the Iqro 'method for children with special needs, including; giving enthusiasm and affection, giving gifts, separating seats for each child, being taught one by one to do repetition of readings so that they are easy to remember and understand, as well as adding image media. The existence of this teacher's effort is able to improve the ability of children with special needs in reading and writing the Qur'an. And the problems that occur in children with special needs in reading and writing the Qur'an have different abilities.
\end{abstract}

Keywords: Islamic Education Teachers; Read and Write; Children with Special Needs.

\begin{abstract}
Abstrak
Penelitian ini bertujuan untuk mengetahui bagaimana upaya guru PAI dalam meningkatkan kemampuan membaca menulis Al-Qur'an melalui metode Iqro', dan mengetahui problematika kemampuan membaca menulis Al-Qur'an pada anak berkebutuban khusus di SLB Bina Sejabtera. Dalam penelitian ini menggunakan metode kualitatif yang memiliki karakteristik alami sebagai sumber data langsung. Subjek penelitian ini di tunjukan pada Guru Pendidikan Agama Islam. Peneliti dalam hal ini menerapkan beberapa teknik pengumpulan data yaitu observasi, wawancara dan dokumentasi. Hasil penelitian menunjukan bahwa upaya guru PAI dalam meningkatkan kemampuan membaca menulis Al-Qur'an melalui metode Iqro' pada anak berkebutuban kbusus adalah; memberikan semangat dan kasib sayang, memberikan hadiah, memisabkan bangku setiap anak, diajarkan secara dituntun satu persatu melakukan pengulangan bacaan agar mudah diingat dan paham, Serta menambabkan media gambar. Adanya upaya guru ini mampu meningkatkan kemampuan anak berkebutuban khusus dalam membaca menulis Al-Qur'an. Dan problematika yang terjadi pada anak berkebutuban khusus dalam membaca menulis Al-Qur'an memiliki kemampuan yang berbeda-beda.
\end{abstract}

Kata Kunci: Guru PAI; Membaca Menulis; Anak Berkebutuban Khusus. 


\section{PENDAHULUAN}

Guru Pendidikan Agama Islam (PAI) memiliki tugas utama yang terletak pada kemampuan pembelajaran agama Islam sehingga dapat dipahami dan dilaksanakan oleh peserta didik secara tepat dan proporsional. Proses mengetahui, memahami, dan mengaplikasikan perlu proses yang matang untuk mengembangkan seluruh potensi yang dimiliki manusia agar agama Islam dapat difungsikan dengn baik (Muchith, 2016: 220) Guru Pendidikan Agama Islam (PAI) memiliki peran sangat penting dalam membangun serta mencerdaskan anak bangsa di setiap lembaga pendidikan. Selalu berupaya dalam mencapai tujuan melalui beragam cara diantaranya: mengajar, melatih, memberi contoh yang baik, memotivasi, memberikan kasih sayang serta mendoakan (R, 2016: 37)

Guru sebagai pembimbing, penasehat, dan menjadi teladan yang baik untuk peserta didik. Peserta didik dengan model yang bermacam-macam, ada anak yang memiliki kesempurnaan jasmani, disamping itu terdapat anak yang memiliki kekurangan jasmani. Anak yang memiliki kekurangan jasmani disebut Anak Berkebutuhan Khusus (ABK). Guru memiliki tanggung jawab bukan hanya kepada anak yang memiliki kesempurnaan fisik tetapi juga kepada anak yang memiliki kekurangan atau berkebutuhan khusus (ABK). Demikian pula dalam pembelajaran Al-Qur'an.
Karena Al-Qur'an adalah kalam Allah diturunkan kepada penutup para Nabi dan Rasul, dengan melalui perantara Malaikat Jibril, ditulis dalam berbagai mushaf, dinukilkan dengan cara mutawatir, membacanya merupakan ibadah, dan dimulai dengan surah Al-Fatihah diakhiri dengan surah An-Nas (Suma, 2014: 23). Sebagai kitab Allah SWT, Al-Qur'an menempati posisi sebagai sumber pertama dan paling utama dari seluruh ajaran Islam. Dan diawal kelahirannya, umat Islam sangat komitmen dengan Al-Qur'an. Mereka bukan hanya menjunjung tinggi kitab ini, namun mereka mampu bersenyawa dan mengaplikasikannya dalam kehidupan sehari-hari.

Setiap mukmin mempunyai kewajiban dan tanggung jawab terhadap kitab sucinya. Diantara kewajiban dan tanggung jawab itu adalah mempelajari serta mengamalkannya. Al-Qur'an merupakan satu-satunya kitab suci di muka bumi ini yang terjaga keasliannya hingga hari kiamat. AlQur'an berfungsi sebagai pedoman hidup yang lurus bagi umat manusia agar hidup selamat dunia dan akhirat. Allah SWT berfirman dalam surah Al-Isra ayat 9, yang artinya: 'Sungguh, Al-Qur'an ini memberi petunjuk ke (jalan) yang paling lurus dan memberi kabar gembira kepada orang mukmin yang mengerjakan kebajikan, babwa mereka akan mendapat pabala yang besar".

Oleh karena itu, merupakan suatu kewajiban bagi seorang muslim untuk selalu mempelajari serta berinteraksi dengan Al- 
Islamic Education Teachers 'Efforts in Improving Reading Ability to Write the Qur'an through The Iqra' Method in Children with Special Needs

DOI: $10.29313 /$ tjpi.v10i1.7847

Qur'an, menjadikannya sebagai sumber inspirasi, berpikir dan bertindak. Membaca Al-Qur'an merupakan langkah pertama dalam berinteraksi dengannya, kemudian diteruskan dengan tadabbur yaitu dengan merenungkan dan memahami maknanya sesuai petunjuk salafus shalih, lalu mengamalkannya dalam kehidupan seharihari, kemudian dilanjutkan dengan mengajarkannya (Indra, 2017: 102).Tidak terkecuali anak berkebutuhan khusus (ABK).

Anak Berkebutuhan Khusus (ABK) merupakan anak yang memiliki karakteristik khusus yang berbeda dengan anak pada umumnya adanya ketidakmampuan mental, serta emosi atau fisik. Anak berkebutuhan khusus juga dapat diartikan sebagai seorang anak yang memerlukan pendidikan yang disesuaikan dengan hambatan setiap individu dalam belajar. Secara fisik, kognitif atau sosial terhambat dalam mencapai potensinya secara maksimal, sehingga memerlukan penanganan secara khusus dan terlatih (Lisinus, 2020: 2$3)$.

Karena anak berkebutuhan khusus (ABK) ini berbeda dengan anak seperti umumnya dan sangat diperlukan penanganan secara khusus, maka guru PAI berupaya melaksanakan pembelajaran dengan menggunakan metode yang sesuai untuk anak berkebutuhan khusus (ABK). Yang perlu diperhatikan oleh guru adalah kemampuannya memilih metode yang sesuai dengan materi dan situasi saat pendidikan berlangsung, juga fasilitas yang tersedia.

$$
\text { Metode dalam pendidikan }
$$
merupakan suatu cara yang digunakan pendidik dalam menyampaikan suatu materi pembelajaran, sebuah keterampilan, keteladanan, atau sikap tertentu agar proses pendidikan berlangsung efektif, dan tujuan pendidikan tercapai dengan baik (Alim, 2014 : 88). Metode dalam kegiatan pembelajaran berfungsi untuk menciptakan pembelajaran dengan baik agar memperoleh kemudahan dalam mempelajarinya (R, 2016: 19).

Pemilihan metode yang tepat akan menentukan keberhasilan proses pendidikan tersebut. Problematika bagi seseorang yang memiliki kelemahan dalam membaca AlQur'an disebabkan oleh faktor yang mempengaruhi. Tingkat kemampuan membaca Al-Qur'an setiap individu berbeda sesuai dengan faktor-faktor yang mempengaruhinya. Yaitu adanya faktor internal dan eksternal. Kondisi fisik normal pada umumnya menjadi faktor penentu keberhasilan individu dalam proses belajar. Misalnya, seseorang yang memiliki gangguan pada lidah tentu akan mempengaruhi tingkat kejelasan saat berbicara dan membaca terutama dalam membaca Al-Qur'an (Mahdali, 2020: 151).

Kemudian dalam memahami situasi dan kondisi pada anak berkebutuhan khusus saat ini, guru PAI berperan penting sekali dalam mendidik anak berkebutuhan khusus 
maka sangat diperlukan sekali sebuah pembelajaran dengan metode yang sesuai khususnya dalam pembelajaran membaca dan menulis Al-Qur'an. Di SLB Bina Sejahtera tingkat kemampuan anak berkebutuhan khusus dalam membaca dan menulis AlQur'an berbeda-beda, maka ada upaya yang dilakukan guru PAI untuk meningkatkan kemampuan membaca dan menulis AlQur'an.

Maka Peneliti merumuskan masalah penelitian yaitu bagaimana upaya Guru PAI dalam meningkatkan kemampuan membaca menulis Al-Qur'an melalui metode Iqro' pada anak berkebutuhan khusus, dan apa problematika anak berkebutuhan khusus dalam kemampuan membaca dan menulis AlQur'an di SLB Bina Sejahtera. Penelitian ini bertujuan untuk mengetahui bagaimana upaya guru PAI dalam meningkatkan kemampuan membaca menulis Al-Qur'an melalui metode Iqro' pada anak berkebutuhan khusus, dan untuk mengetahui problematika anak berkebutuhan khusus dalam kemampuan membaca menulis AlQur'an di SLB Bina Sejahtera.

\section{METODE PENELITIAN}

Dalam penelitian ini jenis metode yang digunakan adalah metode kualitatif. Dengan pendekatan studi lapangan (Field research), bertujuan untuk mempelajari latar belakang keadaan lingkungan maupun individu, sehingga menghasilkan gambaran lengkap (Muhyani, 2019: 222). Serta bertujuan untuk memahami secara mendalam serta untuk menggali makna yang dilakukan subjek (Lisnawati, 2012).

Lokasi penelitian dilakukan di Sekolah Luar Biasa (SLB) Bina Sejahtera yang beralamatkan di Jl. Cigarogol Rt 08/03 Desa Mekarsari, Kecamatan Cileungsi, Kabupaten Bogor. Subjek penelitiannya adalah guru pendidikan agama Islam yang akan memberikan sebuah informasi berkaitan langsung dengan penelitian ini.

Dalam penelitian ini sumber data yang digunakan peneliti yaitu sumber data primer dan data sekunder. Sumber data primer yaitu guru pendidikan agama Islam yang memiliki upaya dalam meningkatkan kemampuan membaca menulis Al-Qur'an melalui metode Iqro' pada anak berkebutuhan khusus. Sedangkan data sekundernya merupakan kepala sekolah, siswa dan orang tua. Serta data yang diperoleh dari berbagai literatur, buku-buku, dokumen, jurnal dan arsip-arsip penting.

Teknik dalam pengumpulan data yang digunakan dalam penelitian ini; wawancara, observasi, dan studi dokumentasi. Jenis wawancara yang digunakan yaitu wawancara tidak tersruktur. Wawancara tidak terstruktur digunakan untuk penelitian lebih mendalam tentang responden yang diteliti agar memperoleh data atau informasi yang lebih dalam dari setiap responden (Sugiono, 2011: 234). Wawancara 
Islamic Education Teachers 'Efforts in Improving Reading Ability to Write the Qur'an through The Iqra' Method in Children with Special Needs

DOI: $10.29313 /$ tjpi.v10i1.7847

dilakukan kepada guru pendidikan agama Islam selaku yang memberikan upaya dalam meningkatkan kemampuan anak berkebutuhan khusus dalam membaca menulis Al-Qur'an. Kepada Kepala sekolah, siswa dan orang tua siswa SLB Bina Sejahtera.

Data yang dikumpulkan dalam observasi, peneliti mengobservasi guru PAI dan siswa dalam proses pembelajaran membaca menulis Al-Qur'an melalui metode Iqro' di SLB Bina Sejahtera, saarana dan prasarana yang tersedia, lingkungan sekolah, serta program-program yang diterapkan terkait dengan proses pembelajaran di SLB Binaa Sejahtera. Dan dokumentasi sebagai cara pengumpulan data melalui peninggalan tertulis, seperti arsip-arsip yang berhubungan dengan masalah penelitian.

Analisis data dilakukan dengan cara memilih data yang dibutuhkan dalam sebuah penelitian. Dalam penelitian ini menggunakan beberapa tahapan yaitu: Pertama, pengumpulan data, dilakukan dengan cara observasi, wawancara dan dokumentasi. Kedua, Reduksi data yaitu pengelompokan informasi yang sesuai dengan masalah penelitian. Sehingga memfokuskan data dalam satu cara hingga kesimpulan akhir dapat digambarkan. Ketiga, Penyajian data yaitu kumpulan informasi yang telah tersusun sehingga memberi adanya penarikan kesimpulan dan pengambilan tindakan (Rijali, 2018). Keempat, Kesimpulan dan verifikasi yaitu penarikan kesimpulan. Peneliti mengutarakan kesimpulan selama penelitian berlangsung kemudian dianalisis data-data yang telah diperoleh dari hasil wawancara dan observasi, sehingga menjadi penelitian berbagai data dapat menjawab permasalahan yang diteliti.

\section{HASIL DAN PEMBAHASAN}

Pada bagian ini akan dikemukakan hasil temuan lapangan yang diperoleh selama penelitian. Dari hasil penelitian yang peneliti lakukan terdapat metode pembelajaran yang dapat meningkatkan kemampuan membaca menulis Al-Qur'an pada anak berkebutuhan khusus di SLB Bina Sejahtera yang dikenal dengan metode Iqro’.

Dalam upaya pengumpulan data peneliti melakukan dengan cara observasi, dokumentasi, dan wawancara secara mendalam yang dilakukan kepada beberapa informan terdiri dari Guru PAI, Kepala sekolah, dan Siswa SLB Bina Sejahtera. Karena mereka memiliki pemahaman serta terlibat langsung dalam pelaksanaan pembelajaran membaca menulis Al-Qur'an melalui metode Iqro' pada anak berkebutuhan khusus di SLB Bina Sejahtera.. 
Upaya guru PAI dalam Meningkatkan kemampuan membaca menulis Al-Qur'an melalui metode Iqro'

Memberikan semangat dan kasih sayang

Anak berkebutuhan khusus (ABK) mampu serta memahami dalam membaca dan menulis Al-Qur'an, tentunya tak henti-henti guru memberikan semangat dan kasih sayang untuknya dalam meningkatkan kemampuan belajar yang dimiliki oleh setiap anak berkebutuhan khusus (ABK). Serta guru lebih memperhatikan kemampuan yang dimiliki anak dengan bimbingan dan pengajaran secara terus menerus serta guru harus mampu memahami karakter yang dimiliki setiap anak berkebutuhan khusus (ABK) SLB Bina Sejahtera.

\section{Memberikan Reward}

Anak berkebutuhan khusus (ABK) ketika mengalami kesulitan dan terus menerus berusaha latihan membaca menulis Al-Qur'an maka kemampuan setiap anak berkembang secara perlahan. Sungguh merupakan kebahagiaan bagi guru di sekolah dan orang tua di rumah akan perkembangan yang dimiliki anak. Tentunya ketika pembelajaran berlangsung terdapat anak yang malas dalam belajar maka guru memberikan reward tidak hanya kepada anak yang mau belajar tetapi untuk anak-anak seperti ini diberikan, dengan memberikan Biskuit yang mengandung susu tentunya bergizi, alat tulis seperti: buku, pensil, penghapus untuk anak dan mereka mau memperhatikan mengikuti pembelajaran dengan baik.

\section{Memisabkan tempat duduk anak}

Guru memisahkan tempat duduk anak dibagi menjadi dua kelompok bagian kanan dan bagian kiri guru berada. Bagian kanan guru merupakan anak berkebutuhan khusus yang mampu dalam membaca menulis Al-Qur'an dan bagian kiri guru merupakan anak berkebutuhan khusus yang tentunya perlu pendampingan ekstra karena belum mampu untuk membaca menulis Al-Qur'an.

Untuk anak yang sudah mampu maka guru memberikan latihan membaca menulis yang tertera di papan tulis dan di tes secara satu persatu. Untuk anak yang belum bisa membaca menulis maka perlu pendekatan oleh guru menghampiri anak tersebut dibimbing secara satu per satu sekaligus melihat kondisi mood anak dan menciptakan suasana yang happy tidak membosankan sehingga anak mau belajar dan kemampuan anak mampu berkembang secara perlahan.

\section{Menambabkan Media Gambar}

Media gambar dipersiapkan oleh setiap guru, dengan cara membuat kaligrafi sederhana untuk pengenalan huruf-huruf hijaiyah memperbesar ukuran hurufnya dan diberikan warna-warna yang menarik tulisan yang dibuat semenarik dan sekreatif mungkin, sehingga anak tidak mudah bosan dan 
Islamic Education Teachers 'Efforts in Improving Reading Ability to Write the Qur'an through The Iqra' Method in Children with Special Needs

DOI: $10.29313 /$ tjpi.v10i1.7847

mampu memahami masing-masing setiap huruf hijaiyah serta mau mengikuti pembelajaran membaca menulis Al-Qur'an.

Anak sambil mewarnai disamping itu guru menanyakan masing-masing huruf dan anak menjawab pertanyaan guru. Tambahan media seperti menjodohkan mencocokkan yang dibuat dalam kertas karton berisi hurufhuruf hijaiyah secara terpisah. Penting sekali tambahan media tersebut karena anak berkebutuhan khusus ( $\mathrm{ABK}$ ) ini cenderung menyukai hal yang bergambar dan berwarna.

\section{Pengulangan secara terus menerus}

Upaya dalam meningkatkan kemampuan anak, guru melakukan pengulangan dalam pembelajaran membaca menulis dengan metode Iqro' ini agar anak paham, mampu serta tidak mudah lupa setiap bacaan yang diajarkan. Karena anak berkebutuhan khusus (ABK) ini jangankan tidak diulang-ulang, diulang saja sebagian anak belum bisa memahami dan mengingatnya, karena ada hambatan di otak yang mempengaruhi kecerdasan (IQ) setiap anak.

Problematika anak berkebutuban khusus dalam kemampuan membaca menulis Al-Qur'an

Kemampuan merupakan daya yang sudah ada dalam diri kita tertanam dalam diri manusia agar bisa mengeksplor serta dipergunakan dengan sebaik-baiknya mampu melaksanakannya. Kemampuan yang dimiliki setiap orang tentu berbeda-beda, sehingga terjadi pada anak berkebutuhan khusus (ABK) ini dalam kemampuan mempelajari membaca menulis Al-Qur'an.

Kemampuan anak berkebutuhan khusus dalam belajar bahwa anak dapat mengikuti pembelajaran dengan baik, mampu membaca dan menulis, mengetahui apa yang disampaikan oleh guru, serta mampu menerapkan dalam kehidupan sehari-hari. Anak berkebutuhan khusus SLB Bina Sejahtera terdapat anak yang mampu membaca dan menulis Al-Qur'an dan terdapat pula anak yang belum bisa membaca menulis Al-Qur'an membutuhkan proses yang cukup dalam mengajarkannya.

Dalam mengajarkan serta membimbing anak berkebutuhan khusus ini harus intens dengan terus menerus diberikan pelajaran dan terus diingatkan. Adanya kemampuan setiap anak berbeda-beda, maka penting sekali guru untuk mendampingi anak secara satu per satu dibimbing olehnya untuk meningkatkan kemampuan anak berkebutuhan khusus ini dalam membaca menulis Al-Qur'an. Adapun kemampuan membaca menulis Al-Qur'an anak berkebutuhan khusus (ABK) SLB Bina Sejahtera diantaranya:

Tuna Rungu

Tuna Rungu memiliki keterbatasan gangguan dalam pengucapan dan pendengaran. Kemampuan anak tuna rungu 
terlihat seperti anak normal pada umumnya, memiliki IQ yang baik, memahami apa yang dijelaskan oleh guru, kemampuan dalam membaca artikulasi suara masih kurang jelas dan mampu dalam menulis. Karena terdapat gangguan dalam pendengaran dan pengucapannya, maka dalam pengucapan menggunakan bahasa isyarat.

\section{Tuna Grabita}

Tuna grahita memiliki gangguan dalam tingkat kecerdasan (IQ) di bawah ratarata tidak seperti anak normal pada umumnya. Kemampuan dalam membaca anak tuna grahita ini sedikit yang bisa dan rata-rata anak tuna grahita belum bisa membaca. dalam menulis masih dalam menebalkan belum

bisa menyalin/menirukan. Karena terdapat IQ/kecerdasan yang kurang dari rata-rata.

\section{Tuna Daksa}

Anak tuna daksa ini memiliki keterbatasan pada fisiknya, terdapat tangan dan kakinya menyilang tidak seperti anak normal pada umumnya, memakai kursi roda, dan perlu dituntun ketika jalan. Kemampuan pada anak tuna daksa ini cenderung pintar dan nyambung ketika mengikuti pembelajaran membaca dan menulis. Kemampuan membaca dan menulis sudah mampu walaupun dalam menulis ukuran hurufnya besar-besar, dan moodnya terkadang berubah seketika. Maka guru harus mengikuti keinginannya agar mau mengikuti pembelajaran dan mood anak kembali membaik.

\section{Tuna Netra}

Tuna netra memiliki keterbatasan pada penglihatan tidak bisa melihat, tapi mampu mendengar.Kemampuan membaca pada anak tuna netra ini menggunakan Braile. Terdapat yang normal sama seperti kita mampu berbicara, serta cepat dalam menghafal dan terdapat pula ketika menghafal dengan terus diulang-ulang karena ada tuna grahita sedikit. Mengajarkan mereka seperti anak normal pada umumnya. Anak tuna netra ini nyambung dan mudah menangkap ketika guru menjelaskan suatu materi.

\section{Autis}

Autis memiliki keterbatasan dalam berkomunikasi dan interaksi, cenderung memiliki tempramental yang kuat. Kemampuan membaca dan menulis mampu dilakukan untuk anak autis ini. Mampu membaca dan menulis paham apa yang disampaikan oleh guru. Dari segi IQ daya kecerdasan yang dimiliki mampu mampu mengikuti pembelajaran. Anak autis terdapat 2 macam diantaranya verbalnya mampu berbicara dan terdapat anak yang suaranya cenderung seperti tuna rungu. Tetapi ditandai ada gerakan-gerakan refleks dari tangan/anggota badan tertentu, jalan-jalan 
Islamic Education Teachers 'Efforts in Improving Reading Ability to Write the Qur'an through The Iqra' Method in Children with Special Needs

DOI: $10.29313 /$ tjpi.v10i1.7847

kesana kemari dan nari-nari. Anak autis ini memiliki kelemahan tidak bisa diberi pelajaran yang berat, karena mudah cape jika berfikir terus menerus dan bisa menyebabkan kejang untuk anak autis ini.

Guru PAI dalam mengajarkan anak berkebutuhan khusus membaca menulis AlQur'an harus ekstra sabar yang kuat dalam mendampinginya. Tidak sedikit mengalami kendala serta kesulitan yang dirasakan ketika membimbing mereka. Guru harus mengetahui ketika anak mengalami mood yang kurang baik dalam belajar, mencari cara untuk mengembalikan mood anak menjadi baik dan mau mengikuti pembelajaran. kendala tersebut diantaranya; (1) Ketika salah satu anak sedang marah tingkat emosionalnya tumbuh maka menjalar keseluruh anak yang lain tidak mau belajar. (2) Anak berkebutuhan khusus $(\mathrm{ABK})$ yang cenderung pelupa maka guru harus selalu mengingatkan diulang-ulang secara terus menerus. (3) kesulitan ketika dalam penglihatan setiap anak karena tidak terlalu jelas untuk melihat secara langsung. (4) kesulitan dalam pemahaman anak kurang nyambung dalam berkomunikasi dan berbicara, maka guru dituntut untuk mengetahui berbagai bahasa isyarat sehingga komunikasi terjalan dengn baik. (5) ketika mood anak bagus/tidaknya dalam pembelajaran, anak moodnya tidak bagus tidak mau mengikuti pembelajaran maka guru mengarahkan ke anak yang lain, membiarkan mood anak yang kurang baik dengan kita memberikan permainan atau bernyanyi dahulu dalam memancing mood anak agar kembali membaik. (6) Kesulitan ketika anak mengeluarkan suara tidak sesuai dengan apa yang dibaca, dan mencari cara untuk anak yang belum bisa mengeluarkan suara artikulasi yang jelas. Serta kesulitan ketika semua huruf dibilang sama semuanya. (7) kesulitan ketika terdapat anak yang tidak paham, tidak nyambung dalam segi kecerdasan yang tidak memadai daya ingatnya.

Ketika anak yang tidak suka dengan gurunya tentu menjadi kesulitan bagi setiap guru. Anak-anak seperti ini berawal dari guru yang disenangi. Sebagai guru tentunya harus bisa memposisikan menempatkan diri kita, jangan sampai kita terlihat tidak sabar di hadapan anak, sekesal-kesalnya kita jangan menunjukan di depan anak-anak. Anak itu mau belajar dengan kita, suka diajarkan oleh kita dengan kita mengetahui karakter setiap anak. Menyelami karakter anak, mendekatinya dengan berbagai cara satu per satu dengan mengontrol setiap anak.

Adanya kendala serta kesulitan yang dialami oleh setiap guru dalam meningkatkan kemampuan anak terutama dalam membaca menulis Al-Qur'an maka kita sebagai guru tidak bisa memarahi anak terhadap keterbatasan yang dimiliki, Karena anak berkebutuhan khusus (ABK) ini tidak merasa bersalah maka guru harus mencari tau penyebabnya apa yang menjadi anak ini 
mengamuk, mood tidak bagus dan lain-lain, oleh karena itu guru harus pandai membaca karakter anak berkebutuhan khusus (ABK) ini, mencari cara agar mood kembali membaik serta mengetahui berbagai cara penanganan untuk anak berkebutuhan khusus (ABK).

\section{KESIMPULAN}

Sesuai dengan hasil pembahasan didapatkan bahwasannya upaya guru pendidikan agama Islam dalam meningkatkan kemampuan anak membaca menulis $\mathrm{Al}$ Qur'an melalui metode Iqro' pada anak berkebutuhan khusus (ABK) ini terdapat banyak berbagai cara yang dilakukan diantaranya: Memberikan semangat dan kasih sayang, Memberikan reward, Melakukan bimbingan secara diulang-ulang satu per satu anak, memisahkan bangku anak, dan menambahkan media gambar dalam proses pembelajaran berlangsung.

Di samping itu, tentu tingkat kemampuan anak berkebutuhan khusus (ABK) SLB Bina Sejahtera tentunya berbedabeda kemampuan yang dimiliki dalam pembelajaran membaca menulis Al-Qur'an. Diantaranya tingkat kemampuan anak berkebutuhan khusus :Tuna Rungu, Tuna Grahita, Tuna Daksa, Tuna Netra dan Autis memiliki kemampuan yang berbeda secara perlahan kemampuan anak akan tumbuh berkembang, dengan guru memberikan pengajaran serta bimbingan yang sabar, kuat, dan intens.

Kendala serta kesulitan yang dialami guru pendidikan agama Islam tentu tidak sedikit dan menjadi tantangan tersendiri untuk dilewati dan terus menghadapi dengan berbagai cara agar pembelajaran berjalan dengan baik serta kemampuan anak terus tumbuh dan berkembang.

\section{DAFTAR PUSTAKA}

Ainayyah, Refiana. 2019. "Identifikasi Komunikasi Anak Berkebutuhan Khusus Dalam Interaksi Sosial.” Jurnal Pendidikan Inklusi 3 (1): 48-52.

Alim, Akhmad. 2014. Tafsir Pendidikan Islam. Ke-1. Jakarta: AMP Press.

Aquami. 2017. "Korelasi Antara Kemampuan Membaca Al- Qur' an Dengan Keterampilan Menulis Huruf Arab Pada Mata Pelajaran Al- Qur' an Hadits Di Madrasah Ibtidaiyah Quraniah 8 Palembang” JIP Jurnal Ilmiah PGMI 3 (1): 77-88.

Arjuna, Khairul. 2018. Bersegeralah. Ke-1. Ponorogo: Uwais Inspirasi Indonesia. Desiningrum, Dinie Ratri. 2016. Psikologi Anak Berkebutuban Kbusus. Ke-1. Yogyakarta: Psikosain.

Ghazali, A. Syukur. 2013. Pembelajaran Keterampilan Berbahasa Dengan Pendekatan Komunikatif Interaktif. Ke-2. Bandung: PT Refika Aditama.

Indra, Delfi. 2014. "Pelaksanaan 
Islamic Education Teachers 'Efforts in Improving Reading Ability to Write the Qur'an through The Iqra' Method in Children with Special Needs

DOI: $10.29313 /$ tjpi.v10i1.7847

Management Program Gerakan

Masyarakat Magrib Mengaji Di

Provinsi Sumatera Barat Study

Komparatif Di Tiga Daerah." Al-

Fikhrah 2 (2): 102-13.

Lisinus, Rafael. 2020. Sebuah Perspektif

Bimbingan Dan Konseling Pembinan

Anak Berkebutuban Khusus. Ke-1.

Medan: Yayasan Kita Menulis.

Lisnawati, Santi. 2012. Penelitian Kualitatif

Pendidikan Agama Islam. Ke-1.

Bandung: PT Remaja Rosdakarya.

Mahdali, Fitriyah. 2020. "Analisis

Kemampuan Membaca Al- Qur' an

Dalam Perspektif Sosiologi

Pengetahuan." Mashdar : Studi Al-

Qur'an Dan Hadits 2 (2): 143-68.

Mahmud, H. 2018. "Upaya Meningkatkan

Keterampilan Menulis Dengan

Teknik RCG (Reka Cerita Gambar)

Pada Siswa Kelas VI SDN Rengkak

Kecamatan Kopang Kabupaten

Lombok Tengah.” JISIP 1 (2): 32-46.

Makhbuloh, Deden. 2011. Pendidikan Agama

Islam. Ke-1. Jakarta: Rajawali Pers.

Muchith, M Saekan. 2016. “Guru PAI Yang

Profesional." Quality 4 (2): 217-35.

Muhyani, Dr. 2019. Metodologi Penelitian Cara

Mudah Melakukan Penelitian. Ke-1.

Bogor: Uika Press.

Nisa, Khairun. 2018. "Karakteristik Dan

Kebutuhan Anak Berkebutuhan

Khusus." Adimas Adi Buana 02 (1):

33-40.
R, Dahlan M. 2016. Konsep Pembelajaran Aqidah Akblak. Ke-1. Yogyakarta: Deepublish.

Rahmatullah, Sumarji. 2018. "Inovasi Pembelajaran

Al-Qur'an.” TA'LIMUNA 7 (1): 60-73.

Riadin, Agung, and Dwi Sari Usop. 2017.

"Karakteristik Anak Berkebutuhan

Khusus di Sekolah Dasar Negeri (Inklusi) di Kota Palangkaraya Children Characteristics of Special Needs in Primary School (Inclusion ) in Palangka Raya." Anterior 17 (1): 22 27.

Subky, Badruddin H. 2015. Tafsir II Pendidikan Islam. Ke-1. Depok: Indie Publishing. Sugiono. 2011. Metode Penelitian Kuantitatif, Kualitatif Dan R\&D. Ke-13. Bandung: Alfabeta.

Suhartono, Tony. 2019. "Manajemen Sekolah Untuk Anak Berkebutuhan Khusus.” Tawazun: Jurnal Pendidikan Islam 11 (2): 1-11.

Sulaiman, Tafsirun. 2011. Al-Qur'an Inspirasi Perubahan. Ke-1. Jakarta: Dian Rakyat.

Suma, Muhammad Amin. 2014. Ulumul Qur'an. Ke-1. Jakarta: Rajawali Pers.

Suprihatiningrum, Jamil. 2013. Guru Profesional: Pedoman Kinerja, Kualifikasi, \& Kompetensi Guru. Ke-1. Yogyakarta: Ar-Ruzz Media.

Syukur, Fatah. 2015. Sejarah Pendidikan Islam.

Ke-2. Semarang: Pestaka Rizki Putra. Tafsir, Ahmad. 2012. Ilmu Pendidikan Islami. 
Islamic Education Teachers 'Efforts in Improving Reading Ability to Write the Qur'an through The Iqra' Method in Children with Special Needs DOI: $10.29313 /$ tjpi.v10i1.7847

\section{Ke-1. Bandung: PT Remaja}

Rosdakarya. 